\title{
Selected Determinants of Mezzanine Financing in Poland
}

\author{
Robert Golej
}

\begin{abstract}
A very significant form of company activity determining its development and even survival is innovation activity. Raising capital for the implementation of innovation is an important but not the only factor in the introduction of innovation. Characteristics of innovation, and in particular the risk of failure, make for a significant difficulty in obtaining external financing, particularly from third parties, which is an obstacle to their development and implementation. The subject of discussion in the article is the hybrid formula mezzanine type of financing innovative projects implemented both in start-up companies and in already well established companies. The purpose of the article is to discuss the possibilities and to perform an analysis of the practices followed by mezzanine funds in Poland in respect to the innovation activities of Polish companies. Research presented in the article was conducted on the basis of information on investments performed by mezzanine funds in Poland.

Of particular importance for the innovativeness of the economy is to have companies from the SME sector, and therefore we also carried out research in this group. Innovations are often initiated in special purpose companies, start-up, etc., that operate in the SME sector. Therefore, the financing of innovation cannot be ignored as a thread of innovation in SMEs. The study involved interviews in several companies in the sector. The study concerned the possibilities of financing innovation involving mezzanine, knowledge of hybrid forms of financing, preparedness for hybrid financing. Studies are not representative, but are rather sounding a view to clarify any further research. Hypothesis: mezzanine financing, utilizing its specific benefits, is increasingly used to finance the gap in the financing of innovation, in particular special purpose companies in the SME sector. So the hypothesis raises two strands of research. The first concerned the financing of innovation as seen from the mezzanine fund. The second concerns the willingness of enterprises to use this form of financing. The first part of the article is devoted to the embeddedness of mezzanine financing. For that purpose, the specific innovation feature decisive to the possibility of external financing was indicated. Various investment strategies of Private Equity Funds on a global scale were presented in a way intended to highlight the meaning and characteristics of mezzanine financing. Also, on the basis of statistical data, the

1 Robert Golej, Ph.D., Wrocław University of Economics, ul. Komandorska 118/120, 53-345 Wrocław, e-mail: robert. golej@ue.wroc.pl.
\end{abstract}


potential market for innovation financing in Poland was indicated. Subsequently the essence of mezzanine type financing and its potential to support development and innovation was presented. Upon this background, an analysis of the possibilities for financing innovation in startups and established companies was conducted. Also, examples of mezzanine financing that took place in Poland in recent years were presented. The article, therefore, is constructed in the form of deductive-inductive analysis.

The conducted research leads to the conclusion that there is a gradual development of mezzanine financing in Poland. The transactions are also diverse as to the industry sector and the size of the investment. There is also a noticeable lowering of the minimum quota of individual investments, which means that the popularity of this form of financing could increase. What needs to be noticed, however, is that mezzanine funds focus their activity on companies in good financial condition, which do not have the credit capacity for the implementation of all their development projects. They have the characteristics of a mature organization. So they have: a strategy, experienced management, good cash flow, good market position and growth potential.

Keywords: innovation, mezzanine, funding innovation, Poland.

\section{INTRODUCTION}

The problem of financing economic activity is accompanying entrepreneurs at every stage of their operation. Enterprises, in order to survive in the market, obtain a competitive position and make a profit, use capital from different sources, and are different in many aspects. For optimal use of capital, it is necessary to determine the current and future financial needs of the company and its availability to the company. Restrictions in its acquisition are the result of internal factors (legal form of the company, its size, financial situation, reputation) and external factors (market access to specific sources of financing) (Kusak, 2006, p. 2). A special form of activities of a company, which determines development and even survival, is innovation activities. The term innovative activities should be understood as a wide range of activities and efforts undertaken in the enterprise in order to improve the current situation. The subject of innovative projects are the products, services, manufacturing technologies, as well as methods of business management and marketing activities, which have not yet been verified by the market (OECD, 2005). This indicates a very high level of investment risk, which in the context of difficulties in raising capital is an important constraint for the development of innovation in enterprises. Thus, the development of the company depends on innovation, and the development and implementation of innovation depends largely on financing options. Of the many ways to finance innovative projects this article attempts to assess the possibility of filling the equity gap, especially in newly established enterprises (start-up), using mezzanine financing. Equity gap 
(Prędkiewicz, 2012) is the difference between the amount of capital available at commencement of the undertaking and the amount of funds needed to implement the project. The purpose of this article is to conduct a discussion on the possibilities and to analyze the practices of mezzanine funds in Poland towards the innovation activities of enterprises. Research presented in the article was conducted on the basis of information on investments made by mezzanine funds in Poland.

In the context of the discussion presented in the article we will limit the scope of innovation to those which require the greatest financial support. Through deductive analysis we will determine possible areas of financing through mezzanine funds, and through induction we will indicate the practices of these funds towards innovative activities of the company. In this way, the purpose of the article will be fulfilled. Gaps in the literature concern the feasibility of financing innovation in the broad sense and the funds mezzanine. The anticipated contribution of this article is to define the main research topics for further research on the financing of innovation through mezzanine funds. The article is intended to determine the level of preparedness of mezzanine funds in Poland to invest in innovative projects and the pre-determined level of knowledge of entrepreneurs on the financing of mezzanine. Section 1 develops the conceptual framework on access to mezzanine finance for innovations in SME for newly started companies in a stable position. Section 2 describes the data, research methodology and basic descriptive statistics, in Section 3 the main empirical results are presented, while Section 4 concludes with a discussion and a conclusion with implications for research.

\section{THEORETICAL FRAMEWORK}

\section{Nature of innovation}

Innovation, or rather the process of transformation of an idea, discovery or invention of a new useful product/service, has characteristics which determine whether the use of funding is possible (Janasz, Janasz, Prozorowicz, Świadek \& Wiśniewska, 2002, p. 31):

- A long and complex life cycle of innovation is difficult to predict beforehand, which results in the fact that its length becomes an individual attribute of each innovative project, and so it is difficult to capture into a standardized framework; This is also due to the rapid progress of knowledge and changing needs of the market,

- Innovative activity is expensive and risky, which results from the nature of the innovation process. Demand for capital increases along 
the development path of the innovation project; and the risk is greater with breakthrough innovations.

The article assumes that the development process consists of seven phases, these are (Cooper, 1993): the creation of ideas; preliminary analysis; analysis of business opportunities; design (prototype); testing; full production; entrance to the market; post-launch analysis. Each of these stages has inherent risks, necessary resources, products of their activities, time, and budget. An integral part of a new product development process is the decision-making process, choosing between projects in a more or less complex manner, followed by the allocation of resources for innovation.

From a financial perspective, the activity of innovative companies manifests itself: with investments in fixed assets, costs of business R\&D, but also in the labor costs of the marketing department, training costs, and often the costs of laboratories, etc. The costs of innovation activity are often not specifically recorded in accounting (by means of appropriate indexation), except for those investments and costs of R\&D activities which are carried out by external providers.

An important factor influencing the "yet to be tested" product is the presence of the different attitudes of buyers and the existence of the related phenomenon of the so-called valley of death, describing the transition from innovator client to early majority clients. This is all the more important upon the growing popularity of completing the product after its introduction into the market. This means that there is a concurrent operation of a launch and a simultaneous improvement of the product, marketing plan and manufacturing (experience curve). This approach, let's call it "marketconcurrent", corresponds well to seed-funds and start-up funds, since the measures involved are gradual after reaching a specified pool of tasks and the results confirm the assumption. The product is developed and perfected at the same time.

For the purpose of this article, the definition of an Oslo Manual (Oslo Manual, 2005, point 147 and 148) is "An innovation is the implementation of a new or significantly improved product (good or service), or process, a new marketing method, or new organizational method in business, workplace organization or external relation". This broad definition of an innovation encompasses a wide range of possible innovations. An innovation can be more narrowly categorized as the implementation of one or more types of innovations, for instance, product and process innovations. The main subject of the research is innovations implemented by companies and disclosed in expenditure on R\&D sector. Of course, spending on R\&D does not cover the entire range of innovation expenditure. 


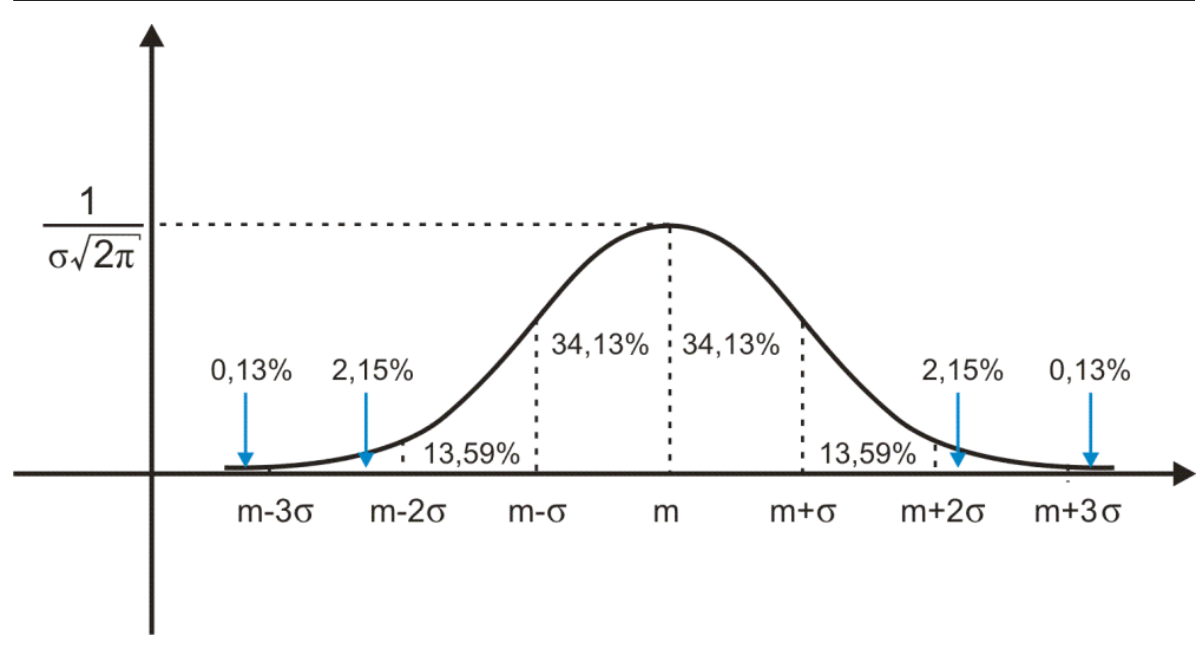

Figure 1. Gauss curve

Source: Retrieved from http://www.naukowiec.org/wiedza/statystyka/rozklad-normalny-rozkladgaussa_710.html (10.10.2016).

Based on the analysis of consumer behavior described by the Gauss curve (Figure 1), five types of customers have been identified:

- $2.5 \%$ - innovators -2 deviations from the mean,

- $13.5 \%$ - the buyer accepting innovations early,

- $34 \%$ - accepting most of the early innovations,

- $34 \%$ - accepting most of the late change,

- $16 \%$ - conservatives.

Analyzing the attitude of buyers in comparison to the Figure 1 (Startup financing cycle) the conclusion is that many newly created entities are not able to cross the threshold of the early majority. This results in the bankruptcy of companies in the early stages of their development and hence there is a strong emphasis on marketing and product perfection. It should be emphasized that it is difficult to obtain the statistical data of how many projects in well established companies actually fail. According to a study by Edgett $(2015$, p. 1) companies willing to work hard at creating innovation capabilities become top performers and realize the benefits. Success rates, in the marketplace, are 2.5 times higher $(63-78 \%)$ than the poor performers that only achieve a $24 \%$ success rate.

In practice, this means that estimating future benefits before crossing this point is highly uncertain. We can say that this is a kind of Rubicon for innovative products / services. This calls for even more precaution, increases the risk, but for those who do not "drown" it will also provide the expected above-average return. 


\section{Financing innovation in SME}

SMEs are one of the essential parts of the knowledge economy. Larger companies, which are the poles of innovation thanks to the activity, flexibility, agility and innovation of SMEs, gain the ability to rapidly deploy product innovations. Innovations in process technology are concentrated in SMEs. Effectiveness and efficiency of individual units of the SME sector increases the effectiveness and efficiency of the entire value chain (Golej, 2013). SMEs improve the dynamic flexibility of business activity and have an influence on improving the overall situation of national economies. SMEs are widely considered to be the source of significant innovation activity (Johnson \& Cathcart, 1979) which increases competitiveness (Song \& Parry, 1997). Gaps in financing innovation in companies from the SME sector will reduce the flexibility and efficiency of the entire system. The ability of SMEs to grow depends highly on their potential to invest in restructuring, innovation and qualification. But all of these investments need capital and therefore access to finance (Giurca Vasilescu, 2010).

Despite specific global efforts to strengthen the SME sector, these companies face a number of barriers to financial and regulatory markets, particularly in developing and emerging countries (Newberry, 2006). At the same time, small and medium-sized enterprises are emerging from the private sector in developing countries and are the basis for the development of the private sector (Hallberg, 2000). It is also recognized that these actors in the economy can be neglected, especially in terms of financial support (Beck, 2007).

Many small businesses start out as an idea from one or two people, who in general, invest their own money. At the next stage, the developing SMEs need new investment to expand or innovate. At this moment, the SMEs begin to face financing problems, because the access to financial resources (banks, capital markets or other suppliers of credits) is more difficult than in the case of larger enterprises (Giurca Vasilescu, 2010).

Alternative forms of financing such as mezzanine capital are becoming more and more a supplement to the traditional forms of corporate financing for SMEs (Brokamp, Hollasch, Lehmann \& Meyer, 2004). It typically involves a mix of debt and equity financing, which allows investors to achieve gains through capital appreciation and interest on debt-repayment.

In summary (Giurca Vasilescu, 2010) it must also be noted that there are several reasons why mezzanine capital can be attractive and feasible. These are:

- the level of control by the finance provider is dependent on the mezzanine product chosen and this gives SME owners the option to retain control of the company, which is one of their main concerns, 
- in contrast to equity capital, mezzanine funds are generally made available for a limited period of time, until the business can generate sufficient "genuine" equity capital from retained profits,

- this form of financing is not appropriate for particular types of companies and business phases such as financial restructurings,

- for companies with a weak market position and negative development prospects; with inadequate finance and accounting function,

- with high leverage, low equity resources.

\section{Mezzanine financing}

Mezzanine finance is not new and has been developing for more than two decades. In the 1980's, the business was dominated by insurance companies and savings and loan associations. By the 1990's, limited partnerships (LPs) had entered the arena. Today, investors include pension funds, hedge funds, leveraged public funds, LPs and insurance companies, as well as banks that have established standalone mezzanine products (Silbernagel \& Vaitkunas, 2006).

Mezzanine capital represents a hybrid form of financing combining the features of equity and debt (Svedik \& Tetrevova, 2015; Welz, 2006; Konecny, 2013). As for the financial concept, it refers to a financial source that is inserted into a corporation's capital structure between the "floor" of equity and the "ceiling" of senior, secured debt (Anson, Fabozzi \& Jones, 2010). Mezzanine capital can have different forms, such as the forms of debt mezzanine and equity mezzanine (Meluzin \& Zinecker, 2009; Volkmann, Tokarski \& Grünhagen, 2010).

Mezzanine capital (Panfil, 2008; Juszczyk \& Nagórka, 2009; Giurca Vasilescu, 2010) is used in the case of the so-called "equity gap". This form of financing is used when a company has no possibility of obtaining the required funds from debt and / or equity financing (equity). Specifically, use of this type of financing is for companies that have exhausted their credit and at the same time their further dynamic development requires additional financing. The most important feature of this type of financing is that the mezzanine type funds accept a higher risk level than that of bank deposits, with a favorable future participation in profits at the completion of the project. At the same time they expect their return to be smaller than that of the current owners, but greater than in the case of new shareholders. Mezzanine financing is an indirect form of financing between debt and equity financing. Because mezzanine financing has features such as equity and debt financing it is called a hybrid. One form of mezzanine financing consists of debt financing plus the so-called equity kicker. An equity kicker takes many forms, but always allows 
for the financing provider to benefit from growth through the acquisition of a small equity share in the future.

The main features of mezzanine financing (Sulima, 2008) are:

- it is long-term, which means that the repayment period is longer than a bank loan,

- often it does not require regular repayments,

- combines elements of debt and equity, part of the commitment is made in cash (in the current debt service), the second part is warrant (the opportunity to take shares issued in the future or purchase them at a preferential price), the so-called equity kicker implemented at the end of the investment if the value of the company has increased (it has the characteristics of equity),

- usually does not require collateral on assets,

- capital providers have non or incomplete ownership rights.

This means that usually mezzanine is a less risky form of investment in relation to stock because in the case of the bankruptcy of the company it is repaid before any payment to the shareholders. Mezzanine financing is used in situations where for various reasons it is not possible to use additional conventional debt financing. A characteristic feature of mezzanine financing is its flexibility compared to ordinary debt. It can manifest itself, for example, in capitalization of accrued interest.

Mezzanine financing is used traditionally to (Sulima, 2008):

- support business expansion through mergers and acquisitions,

- increase the value of the company before the sale of its shares on the stock exchange (IPO or SPO),

- financing of investments, which significantly affect the potential of the company,

- strengthening of working capital in situations of redemption of the shares from a shareholder who has decided to leave the company,

- financing of leveraged buyouts (LBOS), including the buyout of the company by managers (MBO or $\mathrm{MBI}$ ),

- financing of mergers and acquisitions,

- recapitalizations - to allow the payment of higher dividends through company debt,

- refinancing - change of the current financing structure to a more flexible one, which will help with servicing the debt and/or getting out of debt.

Below is a drawing depicting traditionally invested Mezzanine capital (Figure 2). 


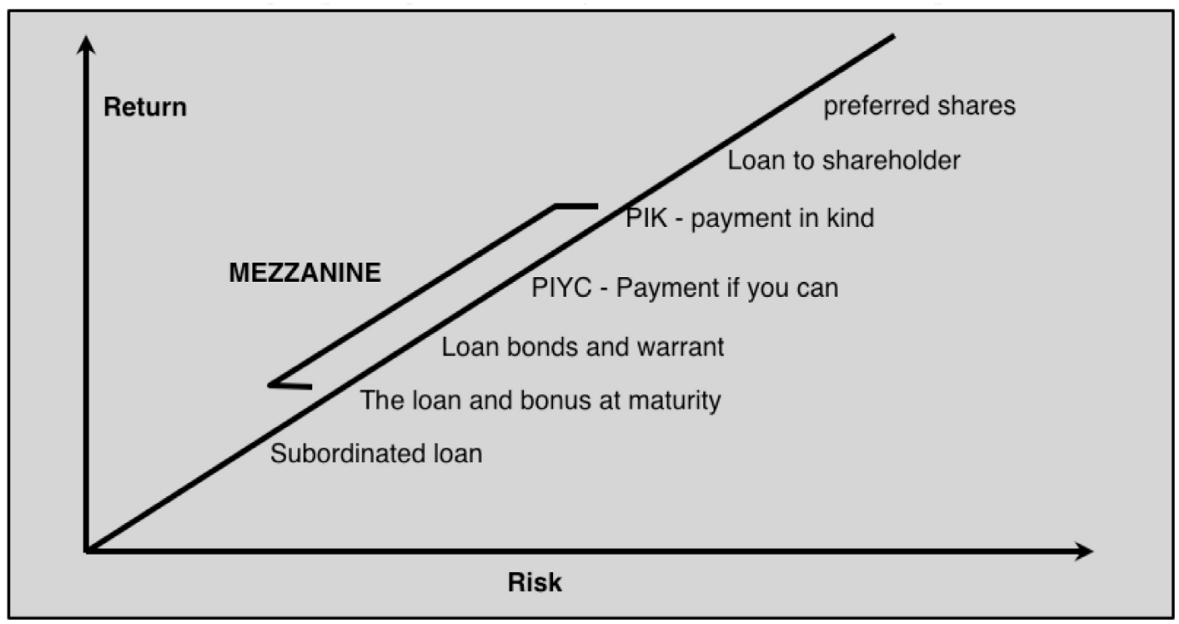

Figure 2. Mezzanine - return and risk relative to other forms of financing company development

Source: Augustyniak (2007).

The main Mezzanine instruments include (Augustyniak, 2007):

- current interest rate,

- interest rates dependent on the results achieved by the company,

- PIYC - pay if you can - the loan is paid at the end of its term, the interest accrued during the initial period, paid in subsequent periods, according to the possibilities,

- PIK - payment in kind - a loan with interest accrued repaid at the end of its term,

- bonds convertible / exchangeable,

- the so-called Equity-Kicker, implemented at the end of the investment if the value of the company has increased (it has the characteristics of equity). The most common form of equity kicker is granting a warrant to the financing entity,

- loans with the elements of capital.

Traditionally, mezzanine financing is designed for medium and large companies with good financial standing, whose creditworthiness is not sufficient for the implementation of all investment plans, and which simultaneously have a defined strategy, experienced management, stable cash flows, established market position, growth potential. Conditions often imposed by mezzanine lenders are (Sulima, 2008):

- maintaining specified levels of financial ratios,

- positive due diligence findings,

- participation in the supervisory board,

- right to information, 
- the right to control of the company,

- participation in decision-making (security provided to third parties, incurring long-term debt, selling assets).

The benefits of mezzanine financing include (Panfil, 2008):

- flexibility in terms of financing,

- lower costs for owners of the enterprise compared with the issuance of public shares or raising capital from a private equity fund. Owners hold unthreatened control over the company,

- repayment of capital only at the end of the contract period,

- availability of financing despite insufficient collateral and creditworthiness.

From the investors' perspective, mezzanine financing also has some advantages, as follows (Giurca Vasilescu, 2010):

- access to a new investment segment,

- returns similar to those on equity,

- investment platform independent of stock and bond markets,

- optimal opportunities for diversification,

- lower exit risk and better protection of capital compared with private equity investments.

There are also a few disadvantages of mezzanine finance for investors such as: the difficulty to exit early and the wrong assessment of creditworthiness leads to lower returns. Besides, the mezzanine provider cannot rely on real security in making an investment decision because mezzanine capital is subordinated and unsecured."

An important criterion for the evaluation of the project is a business idea (Pankiewicz, 2009), most often because projects are financed with a relatively large scale and on the characteristics of a certain innovation. An important element of accessing mezzanine funds is well prepared documentation, including forecasts (Juszczyk \& Nagórka, 2009).

\section{Innovation operator}

Having determined what innovation is, certain qualities of entities implementing innovations have to be indicated. These qualities are decisive in terms of financing options. For the purposes of this article the entities implementing innovations have been separated into two groups. The first group includes companies that are at the early stages of development, their development is harmonized with the innovation process. The second group includes entities with an established position in the market where product innovation is one of the processes taking place in the company. 


\section{Newly formed (startup) firms}

In the case of start-ups, we can distinguish several characteristics which determine the possibilities of raising capital for development. The main features in determining the existence of the equity gap in startup companies are (Brzozowska, 2009, p. 9):

- the phenomenon of vulnerabilities - the requirements of banks regarding security measures for funds granted in a loan,

- lack of credit history,

- often found low levels of knowledge about running a business,

- lack of experience in relations with financial market institutions,

- the resulting high cost of debt capital.

On the other hand, high growth potential inherent in the innovation of the project could be an incentive for investors expecting a high return on capital employed (Duliniec, 2011, p. 113, 76). The basic and traditional forms of corporate finance at an early stage of development are Venture Capital as one of the investment strategy of Private Equity Funds. As defined by the British Venture Capital Association (BVCA), the term "private equity" is related to the financing of non-listed companies, which are in various stages of development (www.bvca.co.uk, 2012). In turn, "venture capital" is a narrower concept, covering only investments at the early stages of enterprise development (Panfil, 2005). Of course, very often the activity of Funds engaged in start-ups continues until the redemption or sale of their shares. It depends, therefore, either on the financial condition of the company or on the willingness of the acquisition by another entity from the industry.

Another early form of innovation funding in start-ups are business angels. In the light of the terms included in the literature, business angels (BA) are defined as private investors who, having capital, knowledge and business experience, financially and technically support a selected company (Angielsko-polski, 2002, p. 25). Just as in the case of PE / VC financing has an equity character, so the investor acquires both corporate and property rights.

Due to their nature, start-ups have limited access to debt financing (loans, bonds, etc.). The Figure 3 below shows a typical course of the cycle of financing entities from idea to full maturity. 


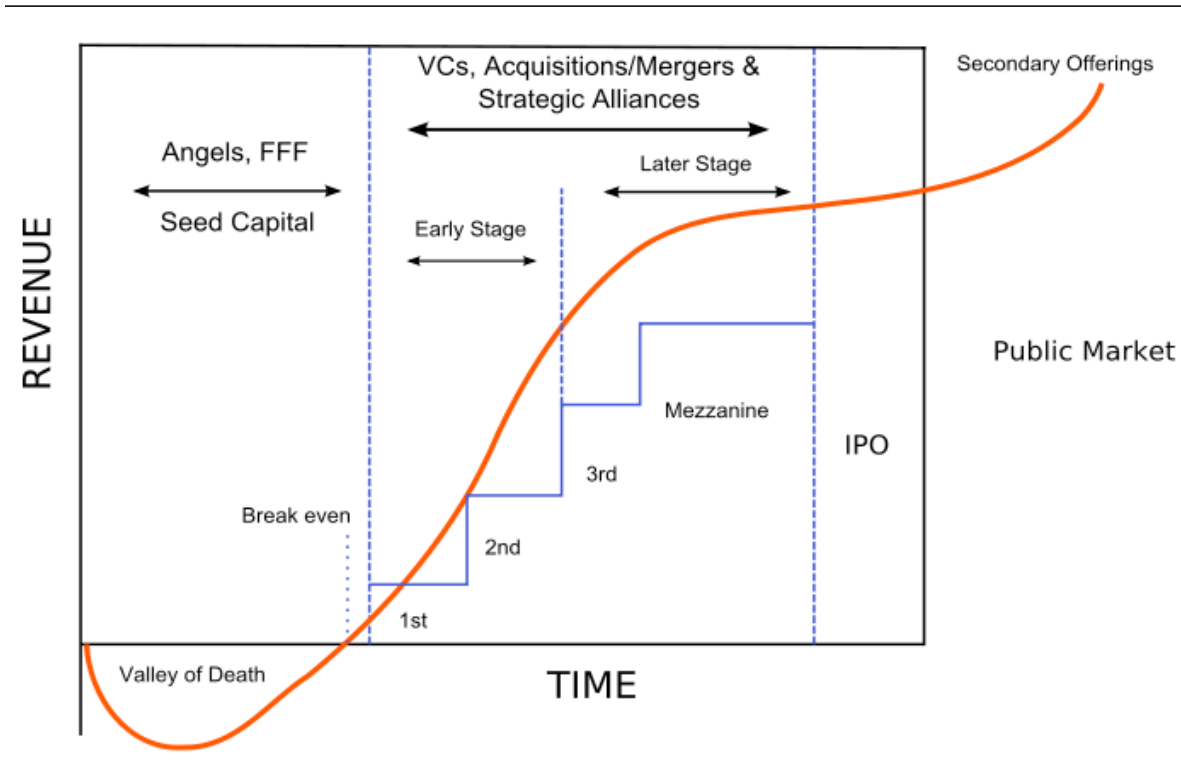

Figure 3. Startup financing cycle Source: Cardullo (1999).

Traditional system indicates that Mezzanine capital will only be used at a later stage for emerging companies as this is the stage of expansion.

Table 1. Phases of new product development in companies newly established with reference to the stages of the investment funds Private Equity

\begin{tabular}{ll}
\hline New product developmemt stage & Investment stages PE/VC \\
\hline Idea Generation & Owner, Team \\
Scoping & Seed capital \\
Build the Business Case & Seed capital, Start-up financing \\
Development & Start-up financing \\
Testing and Validation & Start-up financing \\
Full Production & Early-stage financing \\
Market Launch & Early-stage financing \\
Post Launch Review & Early-stage financing \\
Expansion & Expansion financing \\
\hline
\end{tabular}

Source: Own elaboration based on Cooper (1993) and Panfil (2008).

Table 1 shows the relationship the possibility of financing the various phases of the development process of new products (NPD). phase of the process NPD often determines the form of business and financing sources. This is especially important in new companies. 
A significant part of innovations implemented in the form of new business, which is why it is necessary briefly to characterize the main forms of financing in the early stages of development of the company. We can list four types of investments performed by venture capital (Szydłowski, 2013, p. 93):

- Seed capital financing - the company is organized to carry out a specific innovation (incubation), at the phase of seeding (i.e. share incubation, seed, seed capital). Investments of this type are taken in order to finance a very early stage of the project. It is about all the preparatory activities related to starting a business, such as: product concept development, conducting market research, establishing a management team and business plan development. At this stage answers are given to questions in terms of: product definition (What? And Who?); the justification of the project NPD (Why? Is the market attractive, whether the market is rising? Is the return satisfactory?); resources (Who? What?).

- Start-up financing. The company is already organized and has the first experiences of non-commercial sales of the product in terms of new product development process. We are talking here about the implementation stage of product development and the definition of its final form. At this stage, the entire marketing plan is already created for the new product. In this phase also the design stage is carried out, which is topped with a prototype and technical documentation of the new product. The assumptions of production and distribution are verified.

- Early-stage financing. At this stage the product development is complete. The funds are used to start the production and sale on the market. On the one hand it is a stage characterized by a lower level of risk, on the other hand there is a higher level of capital expenditure. In terms of the product development process the full stages of production, distribution, marketing, and many other related product launch activities will be carried out.

- Expansion financing. This type of investment somehow goes beyond the implementation phase which completes the process of new product development. Investments in this phase relate to companies with stable market position, able to self-finance its current operations. Money from the Funds is used to finance increased production, further product development, marketing activities, and increased working capital. This type of investment concerns the investment in a company with an established position. A detailed demarcation is presented in Figure 4. 


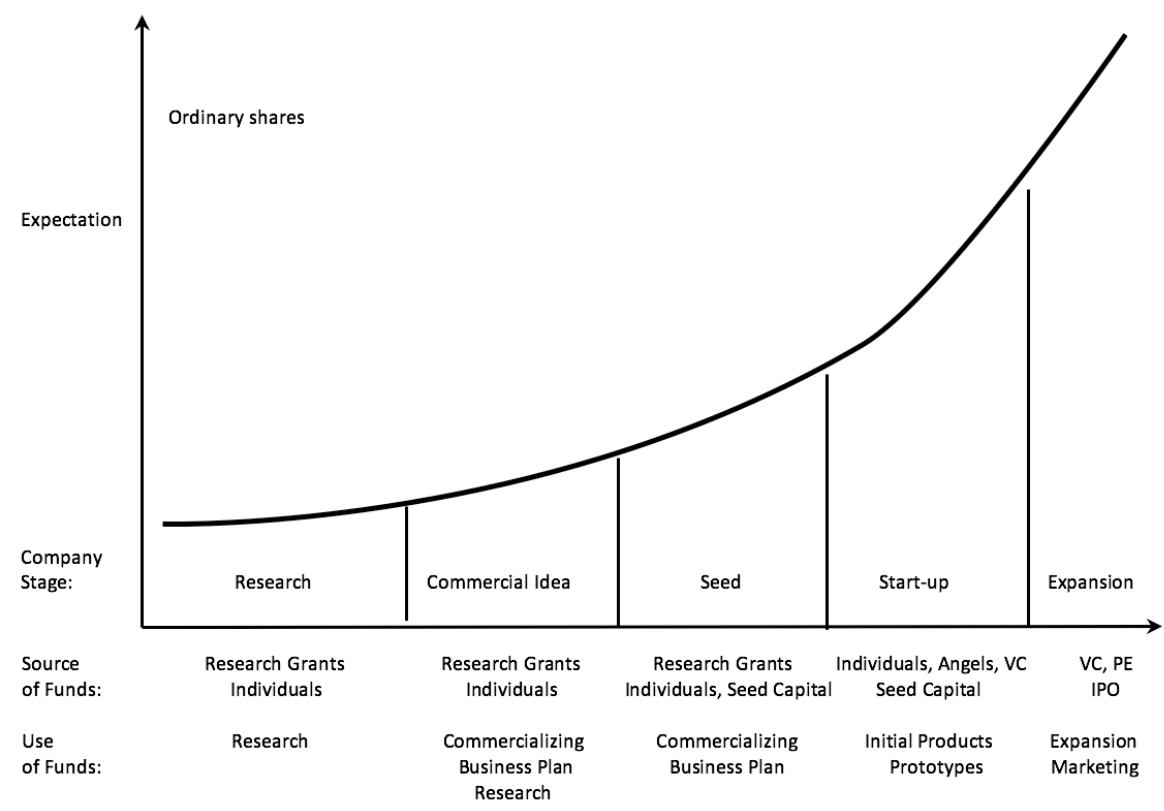

Figure 4. Financing the development of the company

Source: Own study based on Panfil ( 2008).

\section{Company with an established position}

The second group of entities carrying out the processes of the development of innovative products and services are companies with an established market position. For these companies, a financing gap can also occur especially in the context of rapid sales growth. What is also possible is a situation in which spending on innovation will be so high that they justify the funding of innovation in the form of mezzanine but only after using a cheaper form of financing which is credit.

Businesses with an established position can use many different forms of financing which include (Ostaszewski, 2003, p. 59):

- Own external financing - to provide cash for equity, e.g. increased share capital, share premium, excess of value over the nominal value of shares, contributions of partners, venture capital.

- Self-financing - allocating a proportion of net profit for the financing of business assets.

- Debt financing - the use of foreign sources of financing (both of which are of interest as well as those of a non-interest character) bank investment loans, issuance of bonds and other long-term debt 
securities, franchises, short-term bank loans, issuance of short-term debt securities, trade credits and other commitments.

- Hybrid financing - substituting one form of financing to another (most frequently swapping debt financing on their own), or a combination of traditional instruments with derivatives (options, swaps, futures, etc.).

\section{RESEARCH METHODS}

Polish practice of mezzanine financing is interesting because Poland belongs to a group of large European countries, defining a path of development for the countries of central and eastern countries (enlargement of the EU after 2003). Successful processes in Poland are transferred to the rest of the group. Poland is also the leader of the Visegrad Group. In terms of forms of financing in Poland you can find many solutions and examples. The Polish financial market is still a market that is growing, which is also very interesting: How is the market of mezzanine financing in Poland? What is the knowledge of mezzanine financing instruments among entrepreneurs in Poland (educating level)? All the time are open questions about the possibility of using hybrid financing for the funding of SMEs, particularly innovative companies and start-ups on a larger scale.

The study involved interviews in several companies in the SME sector. The study concerned the possibilities of financing innovation involving mezzanine, knowledge of hybrid forms of financing, preparedness for hybrid financing. Studies are not representative, but are rather sounding a view to clarifying further research. These are the questions:

- How to encourage SMEs to this form of financing?

- Are the SMEs prepared for this form of financing?

- Do they have adequate documentation?

- Do they have knowledge of this form of financing, leading to a sense of security?

- Is there an adequate supply of R \& D projects?

- How deep is the market for R \& D?

- Is the model of mezzanine investing working in practice?

- What are the benefits to investors?

- Is there potential for this form of funding to be used in smaller projects?

- How to manage a distributed investment portfolio (small investment unit) by funds offering mezzanine financing, which on the one hand improves security (for diversification), but on the other increases the cost of managing the fund because of the need to participate in the management of SMEs? 
The hypothesis which will be verified during the test is as follows: mezzanine financing, using its internal features are increasingly being used to finance the gap in the financing of innovation, in particular for special purpose companies in the SME sector in Poland. So the hypothesis raises two strands of research. The first concerns the financing of innovation seen from the mezzanine fund. The second concerns the willingness of enterprises to use this form of financing. The study was conducted in two directions. The first concerned the analysis mezzanine transactions on the Polish financial market. For this purpose, data was collected on available information of mezzanine transactions in the fund markets offering this type of financing. Seven funds offering mezzanine financing were identified. Additionally, data was collected on expenditure in the R \& D sector, in order to determine the potential market for the financing of innovation.

The second direction of research examined the demand side in individual companies. The research was exploratory in nature and consisted of conducting free interviews. Interviews were conducted with seven persons (persons who are simultaneously owners and management teams) representing seven players from the SME sector. In this case, we studied knowledge of the concept of hybrid financing and evaluation of the level of interest in this type of financing. They were also asked about the potential possessed documentation and the possibility of its preparation.

\section{ANALYSIS AND STUDY}

\section{Expenditure on R\&D sector}

An important element shaping the market is the demand (supply) to the capital for the implementation of innovations. The only possible approximation spending on innovation is the statistics of expenditures for $\mathrm{R}$ \& D. Expenditures on innovation have been limited to the available data on R\&D expenditures, collected from the companies that file such declarations. Below are Polish Statistical Office data describing the expenditure on research and development in 2015 (Table 2).

Demand for capital for R\&D among enterprises in 2015 amounted to 8411 million Polish zloty (PLN), of which a significant proportion accounted for investment expenditures. 
Table 2. Internal expenditure on R\&D by sector

\begin{tabular}{lll}
\hline Sector [mln PLN] & $\mathbf{2 0 1 4}$ & $\mathbf{2 0 1 5}$ \\
\hline Enterprises & 7532 & 8411 \\
Governmental & 3873 & 4406 \\
Higher education & 4715 & 5215 \\
Private noncommercial investments & 49 & 28 \\
Total & 16169 & 18060 \\
\hline
\end{tabular}

Source: Główny Urząd Statystyczny [GUS] (2016, p. 2).

\section{Investment strategies of private equity}

Another factor affecting the financing of innovation is the investment strategies offered by private equity funds. For a broader view the Table 3 below shows data for the global market (approximate data estimated from graph).

Table 3. Private Equity Strategy - Risk / Return (2002-2012)

\begin{tabular}{llll}
\hline & $\begin{array}{l}\text { Return-Median } \\
\text { Net IRR (\%) }\end{array}$ & $\begin{array}{l}\text { Risk-Standard } \\
\text { Deviation of Net } \\
\text { IRR (\%) }\end{array}$ & $\begin{array}{l}\text { Risk-Coefficient of } \\
\text { Variation } \\
\text { CV }\end{array}$ \\
\hline Early Stage Venture Capital & 8,00 & 19.80 & 2.48 \\
Balanced & 8.20 & 11.00 & 1.34 \\
Late Stage Venture Capital & 9.00 & 17.50 & 1.94 \\
Buyout & 13.00 & 16.00 & 1.23 \\
Mezzanine & 9.30 & 5.20 & 0.56 \\
Fund of Funds & 9.50 & 7.00 & 0.74 \\
Real Estate & 10.50 & 16.00 & 1.52 \\
Growth & 12.00 & 15.50 & 1.29 \\
Infrastructure & 12.80 & 10.10 & 0.79 \\
Natural Resources & 13.50 & 15.10 & 1.12 \\
Distressed Private Equity & 13.60 & 13.00 & 0.96 \\
\hline Source: Own can & & &
\end{tabular}

Source: Own calculations based on (Preqin, 2013).

Most capital is allocated to buyout-type transactions. It should be noted that in the case of Mezzanine there is a low coefficient of variation. This, of course, has consequences as it offers a relatively low level of return, but also in a significantly differentiated level of risk measured by coefficient of variation (Table 3 ).

Mezzanine funds record a 9.3\% return, while these funds also show the lowest coefficient of variation of all the investment strategies. The highest 
return was on Distressed Private Equity with a standard deviation equal to the rate of return. The lowest return was Early Stage Venture Capital with the highest coefficient of variation.

Mezzanine investments are an attractive form of investment for investors with a low appetite for risk, ensuring at least a $4 \%$ return (return - standard deviation) (Table 3).

The following Table 4 shows the scale and direction of engagement in Private Equity and Venture in Poland in the years 2008-2015. Increasingly apparent is the growing activity of Funds in the field of start-ups and a high activity of Funds in the buyout segment.

Table 4. Type of investment by CEE country, Poland 2008-2015 (in € million) 2015

\begin{tabular}{lllllllll}
\hline & $\mathbf{2 0 0 8}$ & $\mathbf{2 0 0 9}$ & $\mathbf{2 0 1 0}$ & $\mathbf{2 0 1 1}$ & $\mathbf{2 0 1 2}$ & $\mathbf{2 0 1 3}$ & $\mathbf{2 0 1 4}$ & $\mathbf{2 0 1 5}$ \\
\hline Seed & 3.87 & 1.10 & 0.00 & 0.48 & 2.5 & 1.6 & 1.82 & 2.92 \\
$\begin{array}{l}\text { Start-up } \\
\text { Later-stage }\end{array}$ & 11.36 & 0.00 & 1.29 & 5.18 & 2.7 & 4.9 & 8.76 & 10.25 \\
$\begin{array}{l}\text { venture } \\
\text { Total venture }\end{array}$ & 42.27 & 0.48 & 6.27 & 16.29 & 3.1 & 16.0 & 11.91 & 6.41 \\
$\begin{array}{l}\text { capital } \\
\text { Growth }\end{array}$ & 57.5 & 1.6 & 7.6 & 22.0 & 8.3 & 22.4 & 22.5 & 19.6 \\
$\begin{array}{l}\text { Rescue/ } \\
\text { Turnaround }\end{array}$ & 0.07 & 6.10 & 4.57 & 1.92 & 3.1 & 0 & 0.00 & 0.00 \\
$\begin{array}{l}\text { Replacement } \\
\text { capital }\end{array}$ & 0.00 & 0.10 & 16.15 & 0.00 & 26.7 & 25.2 & 0.00 & 40.23 \\
Buyout & 531.32 & 411.10 & 341.59 & 481.51 & 383.8 & 226.6 & 161.39 & 748.31 \\
Total & 727.3 & 480.4 & 504.2 & 688.7 & 540.6 & 351.5 & 254.4 & 887.4 \\
\hline
\end{tabular}

Source: Own calculations based on European Private Equity \& Venture Capital Association; www.evca. eu (30.10.2016) also http://www.investeurope.eu/media/504370/invest-europe-cee-statistics-2015.pdf (30.10.2016).

\section{Mezzanine financing in Poland}

The research results for mezzanine transactions in Poland are shown in Table 5. It provides information about known mezzanine transactions in Poland achieved by mezzanine funds. The Table 5 is a contribution to the study of mezzanine financing. 
Table 5. Examples of mezzanine transactions in Poland

\begin{tabular}{|c|c|c|}
\hline $\begin{array}{l}\text { Name } \\
\text { of the Fund }\end{array}$ & $\begin{array}{l}\text { Currently implemented and planned } \\
\text { investments in Poland }\end{array}$ & $\begin{array}{l}\text { Investment data (size } \\
\text { of the investment, } \\
\text { commitment of capital, } \\
\text { phase) }\end{array}$ \\
\hline $\begin{array}{l}\text { Accession } \\
\text { Mezzanine Capital } \\
\text { (the strongest } \\
\text { fund operating } \\
\text { in the area } \\
\text { of mezzanine } \\
\text { financing in } \\
\text { Poland }\end{array}$ & $\begin{array}{l}\text { - Dominium Pizzerias (2013, mezzanine) } \\
\text { - Diagnostyka - Clinical trials in 2011, NA) } \\
\text { - Masterlease - Fleet management (2010, } \\
\text { LBO, NA) } \\
\text { - Wheelabrator / Disa (2008, mezzanine LBO) } \\
\text { - Lux Med - services in the field of health } \\
\text { (2004, 2007, 2008, mezzanine, completed) } \\
\text { - Solaris Bus \& Coach - vehicle manufacturer } \\
\text { ( } 2005, \text { mezzanine, completed) } \\
\text { - Zaberd SA - signs (2005, mezzanine, } \\
\text { completed) } \\
\text { - SAD Sp. o.o. - Distributor of Apple (NA, LBO, } \\
\text { NA) }\end{array}$ & $\begin{array}{l}€ 8-40 \text { mln value of a } \\
\text { single investment } \\
€ 80 \text { mln commitment } \\
\text { in Poland, expansion, } \\
\text { mezzanine, privatization, } \\
\text { refinancing, acquisitions. }\end{array}$ \\
\hline $\begin{array}{l}\text { Derby Private } \\
\text { Equity }\end{array}$ & $\begin{array}{l}\text { - CTL Logistic - TSL (2008, mezzanine, lasts) } \\
\text { - Mieszko - Sweets ( } \mathrm{n} / \mathrm{d} \text { Realized) } \\
\text { - Tłuszczowe -Zakłady w Bodaczowie Sp z o.o. } \\
\text { - Processing of rape (2007, mezzanine, NA) }\end{array}$ & $\begin{array}{l}€ 5-25 \text { mln value of a } \\
\text { single investment } \\
€ 24 \text { mln commitment } \\
\text { in Poland, expansion, } \\
\text { mezzanine, privatization, } \\
\text { refinancing, acquisitions. }\end{array}$ \\
\hline
\end{tabular}

Hanseatic Capital - Lynka Sp z o. o. - promotional solutions $\$ 1-10 \mathrm{mln}$ value of a (NA, NA, NA) single investment NA mezzanine, privatization, refinancing, acquisitions.

Penton Partners - Kujawskie Zakłady Poligraficzne DRUK-PAK \$3-12 mln value of a SA - cardboard packaging (2006, private single investment equity, it takes)

- Fabryka Pierścieni Tłokowych Prima SA - \$34 mln commitment spare parts (NA. Private equity, completed) in Poland, expansion,

- Govena (Fluorescent lamps) mezzanine, privatization, refinancing, acquisitions.

Seaf Polska

- BPSC - Software ERP (1992, equity / \$50-600 thousand value mezzanine, lasts) of a single investment

- MATRAS - Bookstores (1996, 2010, equity, credit tem, it takes)

- PPZP - Pork production (NA)

$\$ 17$ mln commitment

- PUPIL - Pet food (NA) in Poland, start-up - SYMBIO - Vegetables and fruit (1998, stages of development, equity, long-term credit, NA) mezzanine. 


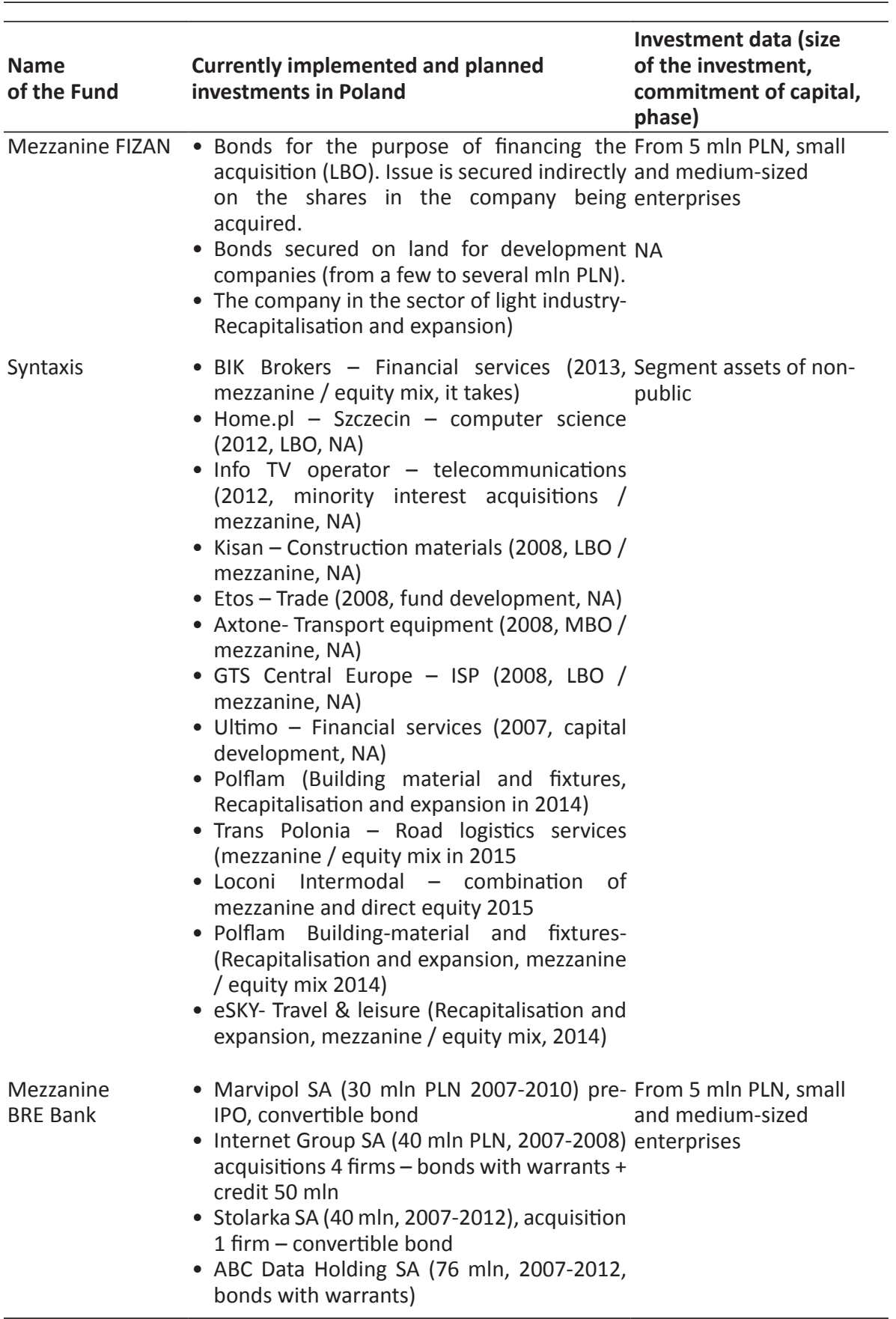

As a result of studies on the structure of mezzanine investments in Poland, which have been included in Table 5, it was found that: 
- the majority of investments involve large projects, greater than 1 million Euro,

- there are investments with a value of less than 250 thousand Euro, targeted to the SME sector,

- there are investment funds offering mezzanine investment, perfectly suited to the Polish market and its characteristics, which facilitates the evaluation of even smaller innovative projects,

- a significant portion of smaller mezzanine investments concerns developer activity, which has little to do with innovation,

- a significant part of the investment relates to LBO transactions,

- often they invest in new business models that combine known solutions such as: Dominion Pizzerias, etc.,

- investments are often of innovation in the business model,

- it seems that an important factor influencing the minimum value of the transaction is fixed costs of the service and the cost of keeping control of the funded company,

- there is a small amount of mezzanine funds directed to the financing of SMEs.

An interesting example of development funding with the use of mezzanine financing is the LUX MED deal (input 2007- exit 2012); bought for 120 million PLN, capitalized at 200 million, then resold to an industry investor for approximately EUR 400 million, giving a profit on the transaction of approximately 640 million PLN. At an annual rate of return of $12 \%$ computed only with the relationship capital expenditures and the selling price, except for the results obtained in the period between the purchase and sale of the company.

\section{Mezzanine financing to SMEs}

On the other hand, mezzanine financing is bespoke with its possibilities and expectations. The studies that were conducted point to these possibilities and expectations of SMEs in financing innovation. The interviews that were conducted with managers and owners of SMEs indicate that:

- the majority of those questioned did not know about mezzanine financing,

- great importance was given to the selection of sources of financing and ownership structure, as business owners strove to maintain a dominant position,

- they do not keep the necessary records that would allow them to apply for mezzanine funds,

- they do not have adequate staff to prepare the required documentation, 
- entrepreneurs showed great interest in mezzanine financing after the presentation of this form of financing.

The presented results of conducted research are also in line with Giurca Vasilescu's findings that (Giurca Vasilescu, 2010):

- SMEs are often not aware of the opportunities and the requirements,

- mezzanine finance is often difficult to obtain by small firms because there are more stringent transparency requirements to meet in order to obtain this type of finance,

- mezzanine finance is more expensive than debt financing,

- the interest component and the debt-like characteristics of mezzanine finance make it difficult for suppliers of mezzanine finance to small firms to arrange an early exit,

- mezzanine finance is in principle unsecured.

\section{DISCUSSION AND CONCLUSION}

Additional liquidity can be obtained from equity investors, but equity is one of the most expensive sources of capital. Besides, equity capital, by its nature, dilutes existing shareholders. As a result, mezzanine capital can be an attractive alternative way to get the needed capital and it can be helpful in financing the start-up, expansion of SMEs, innovation and business transfers.

Studies show that few mezzanine funds invest in innovative solutions, focusing essentially on LBO transactions. In the case of new projects they are usually a significant investment (from 5 million PLN) in new business models and the expansion of already verified marketable ideas. They are mainly for companies with an established position. The hypothesis was therefore only partly confirmed.

The presented data shows that the majority of mezzanine transactions are large buyout type projects. However, there are mezzanine funds in Poland, which use their flexibility to support innovative projects. To a large extent, however, they support the entities in late-stage start-up, expansion, and stable business phase. Some transactions have been oriented to expansion and recapitalization, and thus to the payment of higher dividends. The data also indicate that a part of the transactions are carried out in the construction sector. The nature of the investment in these transactions is often confined to a single building or a housing estate. These projects can create a space to enter mezzanine capital in innovative projects in the earlier stages of development. It should be noted, however, that in the case of entities with an established position, but having a financing gap, mezzanine financing can help to develop new products / services. It seems indeed that the characteristics of mezzanine financing directly meet expectations of 
such companies. Mezzanine investments are made in the sector of industrial production, but also in the services and the construction industry.

It is interesting that in the case of investments with the participation of BA, PE / VC the entire development process of a new product is realized, which is superimposed by the kind of organic growth of the company in the initial stage of its development in the financial part. The advantage of the availability of resources, systems, capital and organizations lies with existing companies. Determination, agility and flexibility are something that the startup companies have and to them each customer symbolizes success. There are many examples of the latter having overtaken the former in the advancement of innovative technologies.

Another conclusion resulting from a comparison of new product development with the development of a company is the fact that, in the case of financing the subsequent phases of development of the company by another specialized institution, we achieve the effect of market allocation, where there is a mechanism of balance and, somehow spontaneously, a funnel effect appears. The decision on the selection of projects is taken by teams of experts authenticating the market and financial success of selected projects, the main criteria being the maximization of economic effects (owninterest). The advantages of VC and mezzanine financing, therefore, should be the process of applying for funding of the project and its wider consultation, because it becomes a filter between the phase of detailed analysis/design and the test phase.

In the case of implementation of the new product development process in established companies there is a hierarchical mechanism of resource allocation in the whole process from the idea to new product market implementation. In this case, in addition to economic motives, also noneconomic motives will play a large role. Thus, the allocation of resources in established companies will be a mixed (hybrid) type.

The arguments presented above indicate that mezzanine type of financing is a good instrument to support the development of enterprises. In the case of startup type entities mezzanine financing can be used at a later stage of growth.

In the case of companies with a strong market position, the scope of cooperation is greatly expanding. This applies especially to knowledge-based firms and technology companies where there may exist a security gap. Like the other companies, not only the security gap, but also the equity gap may exist. The flexibility of mezzanine allows for the use of market opportunities for companies that for various reasons do not have adequate backup to finance their dynamic growth. For them, mezzanine can be a very good tool for financing innovation. 
In Poland, mezzanine funds invest in a variety of industries, but mainly focus on LBO transactions. We observe more and more transactions that support the expansion of businesses. Innovative activity may prove to be an attractive area of financing both to investors and to the supported companies.

It should be emphasized that among the various private equity investment strategies mezzanine funds gain the smallest coefficient of variation, which shows they are relatively low risk.

This article has not been subject to support from the State or the European Institutions, and is independent research and development. Due to pressure, however, the research will have a growing impact on the activity of innovative enterprises.

The studies were exploratory in nature. They showed, however, the interest that SMEs have in financing mezzanine. Research should continue in the direction of the search methods, tools, the restrictions on the use of mezzanine financing as a method limiting the funding gap between equity and senior debt.

The study conducted on investment funds which offer mezzanine finance indicated that more and more often they invest in innovation in the SME sector. Unfortunately, studies have shown that the poor preparation of SMEs and their limited knowledge of mezzanine finance restrict their use of this form of financing. This raises the need for wider promotion and education in the various forms of hybrid financing.

\section{References}

Angielsko-polski słownik terminologiczny programów rozwoju regionalnego. (2002). Warszawa, Poland: Polska Agencja Rozwoju Przedsiębiorczości.

Anson, M. J. P., Fabozzi, F. J., \& Jones, F. J. (2010). The Handbook of Traditional and Alternative Investment Vehicles: Investment Characteristics and Strategies. Hoboken: John Wiley \& Sons.

Augustyniak, S. (2007, June). Mezzanine nie czeka na lepsze czasy - rozmowa z Andrew Philipsem dyrektorem zarządzającym ICG oraz Aleksandrem Ferencem reprezentującym w Polsce ICG. CEO Magazyn Top Managerów. Baruk, J. (2006). Zarzqdzanie Wiedzq i Innowacjami. Toruń: Wydawnictwo Adam Marszałek.

Beck, T. (2007). Financing Constraints of SMEs in Developing Countries: Evidence, Determinants and Solutions. KDI conference on Financing Innovation-Oriented Businesses to Promote Entrepreneurship. Retrieved from https://pure.uvt.nl/ws/files/1107677/Financing_Constraints_of_ SMEs.pdf

Brokamp, J., Hollasch, K., Lehmann, G., \& Meyer, L. (2004). MezzanineFinancing, Bridging the Gap. 2nd Edition, Deloitte. 
Brzozowska, K. (2009). Kapitał wysokiego ryzyka w niwelowaniu luk kapitałowych przedsięwzięć inwestycyjnych, In B. Bernaś (Ed.) Zarzqdzanie finansami firm: teoria i praktyka. Prace Naukowe Uniwersytetu Ekonomicznego we Wrocławiu 48, (pp. 66-75), Wrocław, Poland: Wydawnictwo Uniwersytetu Ekonomicznego we Wrocławiu.

Cardullo, C.M. (1999). Technological Entrepreneurism: Enterprise Formation, Financing and Growth. Baldock, United Kinstong: Research Studies Press Ltd.

Cooper, R.G. (1993). Winning at New Products. Accelerating the Process from Ides to Lunch. Massachusett: Addison-Wesley Publishing Company.

Duliniec, A. (2011). Polish Statistical Office. Finansowanie Przedsiębiorstwa. Strategie i Instrumenty. Warszawa, Poland: PWE.

Edgett Scott, J. (2015). Idea-to-Launch (Stage-Gate $\left.{ }^{\circledR}\right)$ Model: An Overview. Retrieved from http://www.stage-gate.net/downloads/wp/wp_10.pdf

Giurca Vasilescu, L. (2010). Financing gap for SMEs and the mezzanine capital. Ekonomska istraživanja, 23(3), 57-67.

Główny Urząd Statystyczny. (2015). Działalność badawcza i rozwojowa w Polsce w 2015 r. Opracowanie sygnalne. Retrieved from http://stat.gov.pl/ download/ gfx/portalinformacyjny/pl/defaultaktualnosci/5496/8/5/1/ dzialalnosc_badawcza_i_rozwojowa.pdf

Golej, R. (2011), Małe i średnie przedsiębiorstwa jako uczestnik procesu dyfuzji wiedzy i innowacji. Prace Naukowe Uniwersytetu Ekonomicznego we Wrocławiu, Nauki o Zarzqdzaniu, 7(164), 74-89.

Hallberg, K. (2000). A Market-Oriented Strategy for Small and Medium-Scale Enterprises. Washington DC: IFC Discussion Paper World Bank, 40.

Janasz, W., Janasz K., Prozorowicz M., Świadek A., \& Wiśniewska J. (2002). Determinanty innowacyjności przedsiębiorstw. Szczecin, Poland: Wydawnictwo Naukowe Uniwersytetu Szczecińskiego.

Janasz, W., \& Kozioł, K. (2007). Determinanty Działalności Innowacyjnej Przedsiębiorstw. Warszawa, Poland: PWE.

Janasz, W., \& Kozioł-Nadolna, K. (2011). Innowacje w Organizacji. Warszawa, Poland: PWE.

Juszczyk, S., \& Nagórka, A. (2009). Finansowanie typu mezzanine jako rozwiązanie pośrednie między emisją akcji a kredytem bankowym. Zeszyty Naukowe SGGW - Ekonomika i Org. Gosp. Żywnościowej, 78, 4758.

Konecny, Z. (2013). Estimating Cost of Mezzanine Capital. Trends of Economics and Management, 7(16), 57-64.

Kusak, Ł. (2004). Jak wybrać najkorzystniejsze źródło finansowania. Serwis Finansowo - Księgowy, 26(480).

Meluzin, T., \& Zinecker, M. (2009). IPO - The Initial Public Offering as a Source of Financing for Business Development. Brno, Czech Republic: Computer Press.

Newberry, D. (2006). The role of SME in the futures of emerging economies. World Resource Institute. 
OECD, Eurostat. (2005). Oslo Manual: Guidelines for Collecting and Interpreting Innovation Data. 3rd Edition. The Measurement of Scientific and Technological Activities, OECD Publishing.

Ostaszewski, J. (2003). Zarzq̨dzanie Finansami w Spółce Akcyjnej. Warszawa, Poland: Wydawnictwo Difin.

Pankiewicz, J. (2009). Mezzanine a klasyczne finansowanie, Biuletyn Euro Info, 1(09), 4-7.

Panfil, M. (2005). Fundusze Private Equity. Wpływ na Wartość Spółki. Warszawa, Poland: Difin.

Panfil, M. (2008, June). Mezzanine jako źródło finansowania dla przedsiębiorstwa. CEO Magazyn Top Managerów.

Prędkiewicz, K. (2012). Is it possible to measure a funding gap? Zarzqdzanie finansami firm teoria i praktyka, tom II, Prace Naukowe Uniwersytetu Ekonomicznego we Wrocławiu, 271, 152-159.

Rothwell, R. (1992). Successful industrial innovation: Critical factors for the 1990's. R\&D Management, 22(3), 221-239.

Schumpeter, J. (1960). Teoria Rozwoju Gospodarczego. Warszawa, Poland: PWE.

Silbernagel, C., \& Vaitkunas, D. (2006, January). Mezzanine Finance, Bond Capital.

Song, X.M., \& Parry, M.E. (1997). A cross-national comparative study of new product development processes: Japan and the United States. Journal of Marketing, 61(2), 1-18.

Sulima, M. (2008). Pozyskiwanie przez spółkę finansowania typu mezzanine, In M. Panfil (Ed.), Finansowanie rozwoju przedsiębiorstwa. Studia przypadków (pp. 412-429). Warszawa, Poland: Difin.

Svedik J., \& Tetrevova L. (2015). Use of public debt mezzanine instruments in the Czech Republic. Procedia - Social and Behavioral Sciences, 210, 449-455

Szydłowski, K. (2013). Rynek kapitału wysokiego ryzyka jakoźródło finansowania innowacji w przedsiębiorstwach. In A. Buszko (Ed.) Finansowanie Innowacji (pp.89-108). Olsztyn, Poland: Uniwersytet Warmińsko-Mazurski w Olsztynie. Retrieved from http://www.uwm.edu.pl/pro-edu/upload/ file/podreczniki/Zad.2/Finansowanie\%20innowacji.pdf

Volkmann, C.K., Tokarski, K.O., \& Grünhagen, M. (2010). Entrepreneurship in a European Perspective: Concepts for the Creation and Growth of New Ventures. Wiesbaden: Gabler Verlag.

Welz, S. (2006), Mezzanine Financing. München: GRIN Verlag.

\section{Internet sources}

Type of investment by CEE country, Poland 2008-2015. Retrieved from European Private Equity \& Venture Capital Association, www.evca.eu (30.10.2016) and http://www.investeurope.eu/media/504370/investeurope-cee-statistics-2015.pdf (30.10.2016) 
Definition of private equity. Retrieved from http://www.bvca.co.uk (30.05.2012)

Normal distribution figure Retrieved from http://www.naukowiec.org/ wiedza/statystyka/rozklad-normalny-rozklad-gaussa_710.html (10.10.2016)

https://www.analizy.pl/fundusze/fundusze-inwestycyjne/profil-funduszu/ NOB21/Mezzanine-FIZ-AN.html (10.2016)

\begin{abstract}
Polish)
Szczególnq forma aktywności przedsiębiorstwa decydujqcym o jego rozwoju, a nawet przetrwaniu jest działalność innowacyjna. Pozyskanie kapitału na realizację innowacji, jest ważnym ale, nie jednym czynnikiem wprowadzenia innowacji. Cechy innowacji, a w szczególności ryzyko powodzenia sprawiajq, że istnieje istotna trudność pozyskania finansowania zewnętrznego, w szczególności obcego na ich rozwój $i$ wdrożenie. Przedmiotem rozważań w artykule jest finansowanie hybrydowe w formule mezzanine projektów innowacyjnych realizowanych tak w firmach start-up jak i w firmach o już ugruntowanej pozycji. Za cel artykułu przyjęto przeprowadzenie dyskusji dotyczqcej możliwości oraz analizy praktyki stosowanej przez fundusze mezzanine w Polsce wobec aktywności innowacyjnej przedsiębiorstw. Badania przeprowadzono na podstawie informacji o inwestycjach funduszy mezzanine w Polsce.

Pierwsza część artykułu poświęcona jest osadzeniu finansowania mezzanine, w tym celu wskazano cechy innowacji decydujqcej o możliwości ich finansowania zewnętrznego. Zaprezentowane różne strategie inwestycyjne funduszy Private Equity Fund w skali globalnej, w której uwidocznione jest znaczenie i cechy finansowania mezzanine. Wskazano również na podstawie danych statystycznych jaki jest potencjalny rynek finansowania innowacji w Polsce. W dalszej kolejności wskazano istote finansowania typu mezzannine oraz jego potencjalne możliwości wsparcia rozwoju i innowacji. Na tym tle przeprowadzono analizę możliwości finansowania innowacji w firmach typu start-up oraz w firmach o utrwalonej pozycji rynkowej. Na, tym tle zaprezentowano przykładowe finansowania mezzanine jakie miały miejsce $w$ Polsce $w$ ostatnich latach. Praca przybrała zatem formę analizy dedukcyjno-indukcyjnej.

Przeprowadzone badania prowadza do wniosku że, następuje stopniowy rozwój finansowania mezzanine w Polsce. Transakcje sq różnorodne tak, co do branży jak i wielkości inwestycji. Odnotowuje się jednak obniżanie minimalnych kwot pojedynczych inwestycji, co powoduje, że zainteresowanie ta formq finansowania może wzrosnqć. Należny jednak stwierdzić, że fundusze mezzanine swojq aktywność koncentrujq na firmach średnich i dużych w dobrej kondycji finansowej, które nie maja zdolności kredytowej dla realizacji wszystkich przedsięwzięć rozwojowych. Posiadaja one cechy organizacji dojrzałej. A zatem majq: strategię, doświadczony zarzqd, dobre przepływy finansowe, dobrq pozycję rynkowq i potencjał wzrostu. Barierq rozwoju funduszy mezzanine w innowacje realizowane w sektorze MSP, może być koszt stały transakcji oraz koszty realizacji funkcji kontrolnej funduszu w pojedynczej inwestycji. Keywords: innowacje, mezzanine, finansowanie innowacji, Polska.
\end{abstract}




\section{Biographical note}

Robert Golej - Ph.D., assistant professor at the University of Economics in Wroclaw. From the beginning of his career he has been employed at the University of Economics, and is also associated with consulting in industry. From 2002 to 2006 he worked on the issues of innovation, defending a doctorate in innovation management. He is the author of books, articles and studies in the field of company business valuation, innovation, clustering, corporate finance, and controlling. He is an expert at the Lower Silesia Institute of Energy. He is also an associate in the Silesian Aviation Cluster, Rail Cluster and Industrial Automation Cluster. 